\title{
Is there life after debt? Revolution in the age of financial capitalism
}

\section{Ole Bjerg}

Copenhagen Business School, Denmark

\begin{abstract}
What happens to classic Marxist notions of revolution, exploitation and class struggle under the premise that we live in the age of financial rather than industrial capitalism? In this essay I argue that the logic of finance is the main structuring principle of the circulation of value, capital, and money today. Accordingly, we should no longer just think of class struggle in terms of workers and capitalists but also in terms of debtors and creditors. In financial capitalism class is determined by one's position relative to the production of money. This also means that a contemporary idea of revolution is a matter of radical change in the way that money comes into being.
\end{abstract}

\section{Keywords}

Capitalism, exploitation, debt, money, financialisation, revolution

\begin{abstract}
The modern bourgeois society that has sprouted from the ruins of feudal society has not done away with class antagonisms. It has but established new classes, new conditions of oppression, new forms of struggle in place of the old ones. Our epoch, the epoch of the bourgeoisie, possesses, however, this distinct feature: it has simplified class antagonisms. Society as a whole is more and more splitting up into two great hostile camps, into two great classes directly facing each other - Bourgeoisie and Proletariat.
\end{abstract}

Marx and Engels, Manifesto of the Communist Party, 1848

\section{I.}

When Marx and Engels wrote their Communist Manifesto, they identified the bourgeoisie and the proletariat as the two opposing classes in society. The bourgeoisie was the ruling class, living at the expense of the rest of society. The proletariat, in turn, was the potentially revolutionary class. The identification of these two classes was of course built on Marx analysis of society. This was an analysis of industrial capitalism.

Today, the Marxist analysis of class struggle and revolution is both timely and untimely. The analysis of industrial capitalism does not seem to fit the current structure of our economy.

\section{Corresponding author:}

Ole Bjerg, Copenhagen Business School, Solbjerg Plads 3, 2000 Frederiksberg, Denmark.

Email: ob.mpp@cbs.dk 
We do not live in industrial capitalism any longer. That is not to say that industrial production has vanished from the face of the earth. Quite to the contrary, the amount of industrial production at the time when Marx wrote Das Kapital was only a fraction of what it is today. However, the distribution of wealth between different classes in society today does not seem to be determined primarily by the logic of industrial exploitation. If it was not already obvious before, the current financial crisis has demonstrated very clearly that the logic of financial markets has become increasingly important in determining the flows of money and capital, and we would be justified in using the term 'financial capitalism' to capture the defining characteristics of contemporary society. Even though the kind of exploitation pointed out by Marx truly still exists, the distribution of the wealth appropriated through industrial exploitation is itself the object of another form of exploitation. As Marx points out, money in the form of capital is a crucial element in the exploitation of labor. But today not only the functioning but also the very creation of this capital is subject to the conditions of global financial markets and international banking. In an age of financial capitalism, even good old-fashioned industrial capitalists may become the subject of exploitation.

Since the 1970s, societies have been subject to processes of economic liberalisation and financialisation. It is obvious to most people that key sectors of the public infrastructure such as telecommunication, transportation, and energy supply in many countries of the Western world have been privatized, and today are no longer controlled by the state. It is, however, less obvious that even the production of money and the control over the way that money comes into being has also been outsourced to private agents in the form of banks and financial institutions. Today money is no longer just a medium for the production and exchange of goods and services in capitalist societies. The very production of money is a centre point in the accumulation, exploitation, and redistribution of resources on a global scale. This is the age of financial capitalism.

When most people think about money they imagine the coins and notes that we carry around in our pockets. We tend to think that these monies come into being as the central bank coins or prints them. This image is not exactly wrong. It is however strongly misleading as a general theory of money. The vast majority of money circulating in our economies today is not state-created cash money or 'hard cash', but rather credit money based on deposits in private commercial banks (Ryan-Collins et al., 2011) With the evolution of extensive and efficient credit payment systems, together with an equally extensive and efficient system for interbank credit clearance, the creation and circulation of commercial credit bank money has become gradually more and more decoupled from the supply of central bank money. When we borrow money from a bank, this money is not paid out in hard cash but rather just credited to our drawing account. And even when we start using this money, it is not converted into hard cash, but simply transferred from one bank to another through our use of credit cards. We have today created a system in which credit money may circulate among money users and banks, with the state being needed only to bail out the system in times of crisis. Unless you are a drug dealer, a bank robber, or a workman that does a lot of moonlighting, the major part of your monetary transactions are most likely to be made through transfers of credit money to and from your accounts in a bank. Such deposits in a bank are not representations of another kind of 'real' money. This kind of credit money is money.

The privatisation of money creation and the exponential growth in trading volumes on financial markets are two sides of the same coin. As retail banks and investment banks have become increasingly intertwined, financial markets have come to function as an outlet for the perpetual circulation of credit money. This creates a financial demand for credit money, which is readily supplied by banks. The constant innovation of new and increasingly complicated 
financial instruments ensures that the demand for money in financial markets is not restricted by the amount of available goods and other assets in the domain of the real productive economy, but rather remains unlimited. As trading volumes in financial markets greatly exceed the amount of trading in the real productive economy, the pivot point in the determination of the price of money (interest rates, exchange rates, etc.) also shifts toward financial markets. Today the price of money is determined by the sentiments of the markets rather than the political decision-making of central bankers.

If we accept the premise that we live in the age of financial capitalism, this has profound implications for the way we can imagine a revolution. It is beyond the scope of this text to determine whether or not a revolution is in and of itself a good thing. It is easy to demonstrate that the financialisation of capitalism has created a wide range of problems all over the world. It is less easy, however, to demonstrate that revolution is necessarily the best solution to these problems. Revolutions can be beautiful but they are most often very ugly at the same time. But regardless of whether we think revolution is a good thing or a bad thing, it is worth thinking about and imagining what a contemporary revolution might look like.

\section{II.}

The shift from industrial to financial capitalism does not mean that class opposition disappears. Our analysis of society should still include an identification of opposing class interests. In Marx's analysis, class position was determined by the subject's position relative to the means of production. The capitalist class is defined as owners and controllers of the means of production, while the subjects of the labour class own nothing but their own labour, which they are forced to sell to the capitalist. In financial capitalism, the appropriation of wealth and profit is not only - and sometimes not even primarily - mediated through the production and selling of commodities. The very production and circulation of money has become one of the most profitable and influential enterprises of our time. This creates a second axis of class opposition supplementing the classic Marxist distinction between worker and capitalist. While the creation of money was once a state monopoly, the evolution of an economy largely based on credit money has gradually outsourced the privilege for creating money to private banking agents. When this money is sent into circulation in financial markets, it serves to redistribute and appropriate the profits generated in the productive sphere of the economy for the benefits of those agents that are in an advantaged position relative to these markets. In financial capitalism, class position is thus determined by the subject's position relative to the network in which credit money is created and circulated. Ultimately, this criterion renders two opposing classes: debtors and creditors. The creditors are the ruling class while the debtors are the potentially revolutionary class.

The identification and mobilisation of a revolutionary class of debtors is of course made very difficult by the fact that most people are simultaneously debtors and creditors. It is not uncommon for someone to be a debtor by having a mortgage and a bank loan, while at the same time being a creditor on account of having bank deposits or savings in a pension plan that are invested in bonds or stocks. Furthermore, the role of states as major debtors blurs the picture as it is unclear who is actually liable to repay the huge debts accumulated by nationstates such as USA, Italy, Greece, and so on. At this point Marx would of course argue that this blurring of the class boundaries is merely temporary, and that the opposing class interests shall become more and more distinct as history approaches the climatic point of revolution.

The capacity not only to make money but also to make money simply by making money is the defining privilege of the ruling class of creditors. Most money today is issued as debt in the 
form of commercial bank credit. But that is not to say that all debt is money. Many people today are in a position where they can take out a loan and thus create debt. But few people are in a position where they can create a debt that functions as money. This is the difference between people and banks and it is also the fundamental difference between the two classes of debtors and creditors. Creditors are in a position where they can make their own money, or at least they are in a position to benefit from the creation of money. Debtors, on the contrary, cannot make their own money. They therefore have to pay money to use money. In the simplest form, this money is paid as interests. We can think of interests as a kind of tax, which is paid by the debtor for his or her participation in the money system. Today even many nation-states are net-debtors, and interest payments on loans to banks and private investors constitute major items in their budgets. Some of the ordinary taxes paid by citizens are thus converted into the government's payment of 'tax' on the money they use.

In Marx's analysis, surplus-value emerges as the worker produces use-value in excess of the amount of money he or she is paid for his labor. Exploitation occurs as this surplus-value is appropriated by the capitalist. The worker is forced to participate in this exchange of labour for money since he or she does not have the means for valorising labour him or herself. In similar fashion, we can think of interests as a kind of monetary surplus-value. Credit money generates this surplus-value as it must be repaid with an amount of money exceeding the principal. Money users have to engage in this kind of transaction as they do not have the capacity to create their own money. Even if a particular money user is able to stay out of debt by saving up the money he or she needs, interests on this money is still paid by someone else in the system, who has taken out the loan through which the money was originally created. Even if individual money users stay out of debt, the class of debtors as a collective is still subject to monetary exploitation as monetary surplus-value is appropriated by the class of creditors, who are the ultimate source of the issuance of credit money

This way of thinking about interests as the source of monetary exploitation and as a kind of tax paid by money users is of course in contradiction to the way we normally think about interest, and it is certainly in contradiction to the way interests are conceived in mainstream economic discourse. Interest is typically conceived as a kind of rent that the borrower pays to the lender for the right to use their money for a particular period of time. Along these lines, interest compensates the lender for not being able to use the borrowed money for other purposes and for taking the risk that the borrower defaults on the loan. The point here is not to refute entirely conventional notions of interest, but merely to disclose another aspect of money that is veiled in the typical conception. We shall unfold this point through a brief Wittgensteinian analogy.

Imagine that words came into the world with certain ownership rights attached. Every time a language user wanted to use a particular word, he would have to pay a small fee to the original 'owner' who first coined the word. Now such an image is very foreign to the way we normally think about language and most people would be appalled by such a capitalisation of language itself. We do not think of words and language as someone's property but rather as components of a collective system of meaning that is common and shared by everyone who has invested the time and effort in learning the language. The creation of a new word is dependent on the existing reservoir of words. We can credit someone for the idea of coming up with a new word but at the same time it is generally accepted that the creation is indebted to the whole of the language system. Therefore it makes no sense to tax the use of words.

Contrary to language, we tend to think about money as the property of the individual. Money is a system for keeping track of the purchasing power that each individual in the system is entitled to command. While money certainly has this capacity, it is at the same time 
also a collective system that is common and shared by every member of the collective. Just like language, the money system of an economic community works only because the members of the community have structured their social interaction around this money system. In this sense, the beggar and the billionaire contributes equally to the system in so far as both act as if the tokens circulating as money in their community are in fact money. The beggar and the billionaire may differ in the amount of money they own as individuals but they have an equal share in money as a system that structures their economic interaction. "Most things in life automobiles, mistresses, cancer", says J.K. Galbraith (1975: 5), "are important only to those who have them. Money, in contrast, is equally important to those who have it and those who don't". The point here is that the opposite is equally true: People who have it and people who don't are equally important to money. The money of rich people has value only in so far as even poor people accept this money as money.

Once we start thinking about money in these terms, the inevitability with which we accept a money system based largely on interest-bearing credit money seems to disappear. Why must money users put themselves in debt to become part of the monetary system? Why should money users in an economic community pay a fee to particular agents in the money system to be allowed to participate in a system that is only maintained through the common effort and investment of all the members of the community? And what is the moral obligation of debtors to repay their debts, if this debt has been imposed upon them by a system that inevitably creates more debt than what can possibly be repaid? As David Graeber (2011: 372) puts it: "[M]oney has no essence. It's not 'really' anything; therefore, its nature has always been and presumably always will be a matter of political contention". We should insist on the political nature of money because this gives individuals the right to question every aspect of that particular monetary system to which he or she is subject. If democracy is to mean anything in capitalism, it must include the right of citizens to have an influence not only on how the government spends the money of the community, but also on which kind of money should be circulating in the community. If this question is not included in the formal framework of democracy, it forces people to go beyond this framework to exert their democratic influence.

In industrial capitalism, the ultimate political weapon of the working class is the strike. Collective refusal to work puts immediate pressure on the capitalist class of factory owners as it puts the production of value and the accumulation of profit to an immediate halt. It also serves to demonstrate how labor is the ultimate source of value without which no value is created. The displacement of class division from industrial to financial capitalism means that the revolutionary potential of the suppressed class changes. The strike is not an appropriate means of resistance against the class of creditors in a number of ways. First, the class of creditors does not derive profits immediately from the material production of goods. Key agents in financial markets are able to make profits when the market goes down as well as when it goes up. Second, the class of debtors is not identical to the class of workers. In fact, one of the consequences of financialisation and globalisation is the outsourcing of labour to low-wage countries in Asia, South America, and Africa, which means that many people of the traditional working class in the West are out of a job. These people do not even have work that they can refuse to do. Still, this does not mean that they do not have revolutionary potential. What collective strike is to the class of workers in industrial capitalism, collective default is to the class of debtors in financial capitalism. In an economy where most money is ultimately debt, this money not only relies on the money users accepting and believing in this money. It also relies on them to pay back their debts. But if large numbers of people were to collectively refuse to pay their debts this would effectively prevent the system from functioning. 


\section{III.}

It seems that as soon as the financial crisis in 2007-8 was under way it was already identified as a financial crisis. The function of this seemingly innocent naming was that it already structured the field of possible explanations, diagnoses, and solutions to the crisis. One of the diagnoses ruled out by the identification of the crisis as 'financial' was that the problem was not merely what people were doing with money in financial markets, but rather the nature of these monies themselves. The crisis in financial markets was itself merely a symbol of an underlying monetary crisis.

In the immediate wake of the so-called financial crisis there was a brief moment of a few weeks when there was talk of a collapse of capitalism itself. Experts were saying that the economy was finally adjusting itself to the 'real values' of the underlying assets and Marx was even quoted in mainstream newspapers. Publishing houses experienced a sudden rise in their sales of Das Kapital. Yet this general scepticism about the sustainability of capitalism itself was short lived and public concern soon narrowed down into polemics about the pros and cons of stricter regulation for financial markets. I think this brief moment of collective doubt about the basics of capitalism was a revolutionary moment. However, it was a moment of a revolution that did not happen. A revolution that evaporated before it even got under way. Still this moment may be used as an occasion to pose the counterfactual question: What did it look like, this revolution that did not happen?

Even though the underlying causes of the crisis may be traced back several years and even decades to the continuous deregulation of financial institutions and the evolution of increasingly complex financial instruments, the onset of the crisis was sparked by a rapidly rising number of defaults of American homeowners. Defaulting on a mortgage and perhaps a resulting eviction is most often experienced as a personal failure. In itself, a default hardly seems like a revolutionary act. Nevertheless, I think these defaults were precisely elements of a revolution that did not happen. There are three major reasons why these defaults did not lead to revolution.

The first reason why defaulting on a mortgage is not a revolutionary act is that it does not even qualify as an act. Insofar as defaulting on a mortgage is often experienced as a personal failure, it is not considered an intentional result of the will of the defaulter. Instead, a default is usually seen as something brought upon the defaulter by outside forces. The second reason is that the defaults of American homeowners were grasped as merely a series of individual events. The defaults did not effect a collective mobilisation of the debtors. In Marxist terminology, defaulting American homeowners remained a class an sich rather than mobilising themselves into a class of debtors für sich. For the default of American homeowners to have metamorphosed into an act of revolution, the debtors would have had to taken their defaults upon themselves as intentional political acts rather than the result of unfortunate circumstance, and they would have had to use the occasion to realise their collective interest as a class of debtors für sich. The third reason is that the US government stepped in to remedy the consequences of the default. Instead of letting the banks and the financial system take the losses, the government essentially took over some of the debt and hence also carried the consequences of the defaults.

If we take the amount of bonuses paid out to banking executives as a sign of the general health of banks, most of them seem to have recovered pretty quickly from the financial crisis. However, no sooner than economic commentators were starting to call off the alarm of financial crisis did economic emergency re-emerge in the form of a sovereign debt crisis in the US and among European nation-states. Having compensated for the loss of productive jobs to 
China and other non-Western countries through infusions of cheap credit money into their economies, many countries in the West were now suffering as the air went out of the inflated prices of real estate and other kinds of assets that were believed to justify the value of these credit monies. Having to foot the bill for private banks struck by the effects of the financial crisis obviously did not improve the solvency of these countries either.

When countries like Spain and Greece announced severe cuts in public spending to accommodate the demands of Germany and other creditors, which came to the rescue to prevent national default, this was met by public protest. Contrary to the aforementioned events in the US, the response to the effects of the crisis was indeed a collective mobilisation. This was especially the case in Greece, where thousands joined in collective strikes and demonstrations. Indeed, the protest had the contours of the formation of a class für sich.

The problem with the protests in Southern Europe was their target. Since the immediate problems experienced by the people took the form of public spending cuts, their revolt was directed at the government. This meant that the Greeks and the Spanish were mobilising as a collective of dissatisfied citizens and not as a class of debtors. Furthermore, the protests failed to identify the other class who is the true opposition in the class struggle. This of course is the class of creditors. The state comes to function as a buffer between the two classes, which veils the real underlying class antagonism. The problem is not that the state imposes the consequences of its indebtedness onto the people. The problem is that the state has allowed private agents to profit by flooding the economy with credit money of their own making in the first place.

Already Marx was sceptical about the state. In his analysis, the state merely serves to enforce the interests of the ruling class. This is a very crude claim and it does not seem to immediately correspond with the functioning of contemporary states and particularly not those that like to think of themselves as welfare states. Still, when we look at the way that Western governments have responded to the financial and sovereign debt crises, it is difficult not to see their initiatives as so many attempts to protect the position and the interests of the class of creditors. Combining this with an attention to the way that governments and central banks have gradually been outsourcing control over the pricing and supply of money to private banks and financial markets over the course of the past four decades, it seems increasingly difficult to imagine a monetary revolution in the age of financial capitalism without also a struggle between the class of debtors and the state.

In an ideal form, the monopoly of the state to coin money is a monopoly of the people to make their own money. Today, however, the privilege of the state to create money is typically utilised only to support the private banking system in times of crisis. In other words, the state monopoly to create fiat money is primarily used to support the creation of credit money by private banks. The situation is comparable to one in which the state monopoly on violence enjoyed by the police and the military were used merely to protect and maintain the power of private cartels of gangsters. A popular revolution in financial capitalism would not only entail collective default by the class of debtors. It would also require the people to reclaim the right to make money by breaking the state monopoly on money. This is equivalent to Marx's call upon the workers to reclaim control over the productive capacity of their own labour power. The purpose of breaking the state monopoly on money is two-fold. First, it serves to insist that money is indeed a political and not merely a technical issue. In a democracy, we need to be constantly asking ourselves if our current money system is indeed the most appropriate given the political goals and visions we hold. Second, experimentation with alternative forms of money stimulates our collective capacity for monetary imagination. Perhaps it is possible to come up with alternative or even just complementary forms of money that would be better 
suited to deal with some of the economic, societal and environmental challenges that we face today. There are a number of ways in which non-state based currency money could be issued and circulated and there are already numerous experiments with alternative money systems going on around the world. It is beyond the scope of this essay to review all of the ideas of alternative monetary systems - such as local currencies, public banking, free banking, negative interest money, barter circles, Bitcoin, international currency, and so on - that are already in circulation, even though they are struggling to find their way into the mainstream.

However, I do want to end by pointing to one particular proposal for reform. This proposal is particularly interesting because it reconfigures the usual coordinates of political thinking by short-circuiting the relation between the revolutionary and the conservative. In the context of the UK, the proposal was first put forward by Joseph Huber and James Robertson (2000) of the New Economics Foundation, who called for 'seigniorage reform', and subsequently by the new movement for monetary reform spearheaded by Positive Money (see Jackson and Dyson, 2013). In a US context, a proposal along the same lines has been made by Jaromir Benes and Michael Kumhof (2012) of the International Monetary Fund, who have called for a return to Henry Simon and Irving Fisher's original 'Chicago Plan' of 100\% reserve banking from the 1930s. In the non-English speaking world similar proposals for reform have been launched under the headlines of 'Vollgeldreform' and 'bankvæsen med fuld reserve' (Binswanger et al., 2012).

The gist of all of these proposals is a banking reform to restore and extend the prerogative of the state to issue money to include non-cash credit money. Such reform would require private commercial banks to back all outstanding credit with an equivalent deposit of government issued fiat money in the form of cash or credit with the central bank. This would mean that private banks were prevented from creating new credit money that is merely backed by the corresponding debt of money users, or by the debt of other agents in the private banking system. Private banks would no longer be able to create new deposits that are nothing but the outstanding debt of the bank itself. Instead, they would only be able to lend out money that they had subsequently retained, earned, or borrowed in the form of central bank money. In the same way that a person can only lend out a bicycle, a wrench, or a cup of salt if he or she is already in possession of a bicycle, a wrench, or a cup of salt, private banks would now only be able to lend out money that they already possess.

The potential effects of such seemingly simple reform should not be underestimated. It is fair to say that they might even be considered revolutionary. First, control of the money supply would be shifted from commercial banks and credit markets to the central bank and the government, which would restore the government's capacity to apply measures of monetary policy in order to stabilise the economy, and perhaps even steer economic development towards specific societal goals such as equality or sustainability. Second, the profits from issuing new money (seignorage) are reclaimed by the central bank and made available to the government for public spending rather than being appropriated by for-profit private banks and distributed to shareholders, managers, speculators, or other members of the current monetary aristocracy. Rather than borrowing from private banks and investors in international capital markets at variable interest rates, the state would be able to borrow at zero interest from its own central bank, thus reducing or even eliminating the growing volume of debt that is currently burdening many national economies. And third, the risk of bank runs and monetary collapse would be eliminated as banks would have no other liabilities than what is immediately covered by their reserves of central bank money.

As the balance of power and profit is shifted from private banks and financial markets to national governments, the outcome of the proposed reform is of course only as good as the 
political institutions governing the creation of money. There are no guarantees that the economic forces reclaimed by the government are not channeled into warfare, reckless deficit spending, corruption, suppression of political opponents, preferential treatment of political allies, or other stupidities. This would depend on the quality and strength of the political community supporting the monetary system. However, we do not need our governments to be perfect for the proposed reform to be a success. It is enough for them to be just marginally better than the bankers and traders that are currently running things.

As much as these revolutionary potentials may spark the dream of a better, more equal, and even more sustainable world to emerge from out of our current times of crisis, the true beauty of the reform lies in its utter conservatism. What is being proposed is not a new and foreign utopia about money, government and banking. The restoration of the state's prerogative to make new money and the reduction of banks into mere financial intermediaries that lend rather than create money would do nothing but make both parties conform to the idea of what most people already erroneously believe they are doing.

\section{References}

Benes, J. and Kumhof, M. (2012) The Chicago Plan Revisited. IMF Working Paper, 12/202. Available at: <https://www.imf.org/external/pubs/ft/wp/2012/wp12202.pdf/>. Accessed 20 August 2014.

Binswanger, H.C., Huber, J., and Mastronardi, P. (2012) Die Vollgeld-Reform: Wie Staatsschulden abgebaut und Finanzkrisen verhindert werden können. Solothurn: Zeitpunkt Verlag. Galbraith, J.K. (1975) Money: Whence It Came, Where It Went. Boston: Houghton Mifflin. Graeber, D. (2011) Debt: The First 5,000 Years. New York: Melville House.

Huber, J. and Robertson, J. (2000) Creating New Money: A Monetary Reform for the Information Age. London: New Economics Foundation.

Jackson, A., and Dyson, B. (2013) Modernising Money: Why Our Monetary System Is Broken and How It Can Be Fixed. London: Positive Money.

Ryan-Collins, J., Greenham, T., Werner, R, and Jackson, A. (2011) Where Does Money Come From? A Guide to the UK Monetary and Banking System. London: New Economics Foundation. 